\title{
Pengaruh kemampuan numerik dan spasial terhadap hasil belajar matematika siswa kelas VIII SMP
}

\author{
Juliyanti $^{1 *}$, Sudi Prayitno ${ }^{2}$, Amrullah ${ }^{2}$, Ketut Sarjana ${ }^{2}$ \\ ${ }^{1}$ Mahasiswa Pendidikan Matematika, FKIP, Universitas Mataram, Mataram \\ 2 Pendidikan Matematika, FKIP, Universitas Mataram, Mataram \\ juliyanti050@gmail.com
}

Diterima: 16-09-2021; Direvisi: 26-09-2021; Dipublikasi: 30-09-2021

\begin{abstract}
This study aims to determine the effect of numerical and spatial ability on mathematics learning outcomes of students class VIII of SMPN 2 Labuapi. This types of research is ex post facto research with a quantitative approach. The population of this study was students of class VIII SMPN 2 Labuapi. In determining the sample, the probability sampling technique is used with the types of cluster random sampling. The sample in this study were students of class VIII-B SMPN 2 Labuapi totaling 30 people. The data collection techniques used were test and documentation. This research uses statistic descriptive statistical analysis techniques and inferential statistical analysis techniques. The result obtained indicate that there is an influence on numerical and spatial ability on the mathematics learning outcomes of class VIII students of SMPN 2 Labuapi with an effect of $76,6 \%$.
\end{abstract}

Keywords: numerical ability; spatial ability; mathematics study result

\begin{abstract}
Abstrak
Penelitian ini bertujuan untuk mengetahui pengaruh kemampuan numerik dan spasial terhadap hasil belajar matematika siswa kelas VIII SMPN 2 Labuapi. Jenis penelitian yang digunakan adalah penelitian ex post facto dengan pendekatan kuantitatif. Populasi dari penelitian ini adalah siswa kelas VIII SMPN 2 Labuapi. Dalam menentukan sampel digunakan teknik probability sampling dengan jenis cluster random sampling. Sampel dalam penelitian ini adalah siswa kelas VIII-B SMPN 2 Labuapi berjumlah 30 orang. Teknik pengumpulan data yang digunakan adalah tes dan dokumentasi. Penelitian ini menggunakan teknik analisis statistik deskriptif dan teknik analisis statistik inferensial. Hasil penelitian yang diperoleh menunjukkan terdapat pengaruh kemampuan numerik dan spasial terhadap hasil belajar matematika siswa kelas VIII SMPN 2 Labuapi dengan pengaruh sebesar 76,6\%.
\end{abstract}

Kata Kunci: kemampuan numerik; kemampuan spasial; hasil belajar matematika

\section{PENDAHULUAN}

Pengajaran di sekolah menengah meliputi berbagai macam mata pelajaran, salah satunya adalah pelajaran matematika. Matematika merupakan mata pelajaran yang diberikan kepada siswa mulai dari sekolah dasar guna membekali siswa dengan kemampuan berpikir logis, rasional, kritis, cermat, sistematis, kreatif, efektif, dan efisien. Matematika juga merupakan ilmu universal yang mendasari perkembangan teknologi modern, mempunyai peran penting dalam berbagai ilmu dan memajukan daya pikir manusia. 
Berdasarkan hasil observasi peneliti diperoleh bahwa dalam proses pembelajaran matematika siswa di SMPN 2 Labuapi masih mengalami kesulitan dalam menyelesaikan soal berbentuk cerita. Hal ini dikarenakan kurangnya pemahaman siswa dalam memahami materi pembelajaran, kurangnya berlatih mengerjakan soalsoal cerita, kurangnya keterampilan atau kemampuan berhitung siswa itu sendiri, serta kurang tepatnya dalam menerapkan rumus. Kenyataan ini diperkuat berdasarkan hasil jawaban siswa ketika peneliti memberikan soal kepada siswa untuk dikerjakan, siswa masih belum paham maksud dari soal yang diberikan sehingga salah menjawab, keliru dan asal-asalan menggunakan rumus untuk menyelesaikan soal yang diberikan, siswa mengalami kesulitan dalam membayangkan bangun ruang ke dalam ilustrasi gambar dengan tepat dan benar, dan ada juga siswa yang tidak menggambar terlebih dahulu sebelum menyelesaikan soal yang diberikan. Keadaan demikian menyebabkan hasil balajar siswa menjadi rendah.

Menurut Slameto (2013) Ada banyak faktor yang mempengaruhi hasil belajar siswa antara lain faktor internal dan faktor eksternal. Faktor internal adalah faktor yang berasal dari dalam diri siswa sendiri, yang meliputi intelegensi (IQ), perhatian, minat, bakat, motif, motivasi, kognitif, dan daya nalar siswa. Sedangkan faktor eksternal adalah faktor yang berasal dari luar diri siswa sendiri, yang meliputi lingkungan sekolah, lingkungan keluarga, lingkungan masyarakat, keadaan sosial, dan keadaan ekonomi. Dalam penelitian ini memfokuskan pada faktor internal terhadap hasil belajar siswa, yaitu intelegensi (IQ). Di mana Faktor intelegensi dalam pembelajaran matematika terdiri dari kemampuan verbal, kemampuan spasial, kemampuan numerik (logis matematis), dan kemampuan penalaran (Novitasari, Rahman, \& Alimuddin, 2015).

Salah satu kemampuan yang telah disebutkan di atas mempunyai peranan penting terhadap hasil belajar matematika siswa, yaitu kemampuan numerik. Menurut Irawan (2014) kemampuan numerik adalah kemampuan dalam menggunakan angka-angka dan penalaran (logika) meliputi di bidang matematika, mengklasifikasikan dan mengkategorikan informasi, berfikir dengan konsep abstrak untuk menemukan hubungan antara suatu hal dengan hal lainnya. Kemampuan numerik mempunyai komponen khas, yaitu kepekaan serta kemampuan untuk membedakan pola bilangan atau angka dan kemampuan menangani rangkaian penalaran panjang, sehingga seseorang yang mempunyai kemampuan numerik mempunyai cara berfikir yag teratur dalam mengerjakan sesuatu dan menyelesaikan masalah (Indrawati, 2013). Menurut Jayantika, Ardana, dan Sudiarta (2013) seseorang dengan kemampuan numerik yang baik mampu mengelola logika dan melibatkan proses berpikir logis, berhitung, menyusun pola hubungan, dan memecahkan masalah. Dengan demikian, akan berdampak pada hasil belajar matematika yang baik pula.

Selain kemapuan numerik, salah satu kemampuan yang dapat berpengaruh terhadap hasil belajar matematika siswa, yaitu kemampuan spasial. Menurut Harmony dan Theis (2012) kemampuan spasial adalah kemampuan untuk menangkap dunia ruang 
secara tepat atau dengan kata lain kemampuan untuk memvisualisasikan gambar, yang di dalamnya termasuk kemampuan mengenal bentuk dan benda secara tepat, melakukan perubahan suatu benda dalam pikirannya dan mengenali perubahan tersebut, menggambarkan sesuatu hal atau benda dalam pikiran dan mengubahnya dalam bentuk nyata, mengungkapkan data dalam bentuk grafik serta kepekaan terhadap keseimbangan, relasi, warna, garis, bentuk dan ruang. Dalam kemampuan spasial diperlukan adanya pemahaman kiri kanan, pemahaman perspektif, bentukbentuk geometris, menghubungkan konsep spasial dengan angka, dan kemampuan dalam transformasi mental dari bayangan visual (Achdiyat \& Utomo, 2017). Pemahaman-pemahaman tersebut sangat diperlukan dalam mempelajari matematika. Dalam bidang spasial diperlukan kemahiran yang akan memudahkan siswa dalam menyelesaikan masalah yang berkaitan dengan penggunaan gambar, sehingga akan berdampak terhadap hasil belajar matematikanya.

Beberapa penelitian terdahulu, seperti penelitian yang dilakukan Achdiyat dan Utomo (2017) manyatakan bahwa terdapat pengaruh yang signifikan antara kecerdasan visual-spasial dan kemampuan numerik secara bersama-sama terhadap prestasi belajar matematika. Dengan demikian, kemampuan numerik yang berkembang dengan baik dalam diri siswa serta didukung dengan kemampuan spasial yang baik pula mampu membantu siswa dalam menyelesaikan soal-soal yang berkaitan dengan kemampuan mengelola angka dan logika dan menciptakan imajinasi bentuk dalam pikirannya maupun dalam wujud benda-benda tiga dimensi atau membayangkan posisi suatu objek geometri setelah objek tersebut mengalami perputaran dan pencerminan. Oleh karena itu, penelitian ini menunjukkan terdapat pengaruh kemampuan numerik dan spasial terhadap hasil belajar matematika siswa kelas VIII SMPN 2 Labuapi.

\section{METODE PENELITIAN}

Jenis penelitian ini adalah penelitian ex post facto dengan pendekatan kuantitatif. Variabel yang diteliti yaitu kemampuan numerik (X1), kemampuan spasial (X2), dan hasil belajar matematika (Y). Populasi dalam penelitian ini adalah siswa kelas VIII SMPN 2 Labuapi yang berjumlah 115 siswa. Sampel dalam penelitian ini berjumlah 30 siswa dengan teknik pengambilan sampel yaitu cluster random sampling. Intrumen penelitian yang digunakan adalah tes dan dokumentasi data nilai ujian akhir semester yang diperoleh dari guru matematika.

Validitas yang digunakan dalam penelitian ini adalah validitas isi dengan meminta pertimbangan ahli (expert judgement). Adapun yang menjadi validator ahli adalah 2 orang dosen pendidikan matematika FKIP Universitas Mataram dan 5 orang guru mata pelajaran matematika. Teknik analisis data yang digunakan dalam penelitian ini adalah teknik analisis statistik deskriptif dan teknik analisis statistik inferensial. Analisis statistik deskriptif digunakan untuk mendeskripsikan gambaran umum mengenai kemampuan numerik, kemampuan spasial, dan hasil belajar matematika siswa dengan pengategorian digunakan Tabel 1 berikut (Riwidikdo, 2010). 
Tabel 1. Kategori Penskoran

\begin{tabular}{|c|c|}
\hline Interval Nilai & Kategori \\
\hline$X>\bar{X}+1,5 s d$ & Sangat Tinggi \\
\hline $\bar{X}+0,5 s d<X \leq \bar{X}+1,5 s d$ & Tinggi \\
\hline $\bar{X}-0,5 s d<X \leq \bar{X}+0,5 s d$ & Sedang \\
\hline $\bar{X}-1,5 s d \leq X \leq \bar{X}-0,5 s d$ & Rendah \\
\hline$X<\bar{X}-1,5 s d$ & Sangat Rendah \\
\hline
\end{tabular}

Keterangan: $X=$ Skor responden

$$
\begin{aligned}
\bar{X} & =\text { Mean } \\
s d & =\text { Standar deviasi }
\end{aligned}
$$

Selanjutnya dilakukan analisis statistik inferensial, yaitu analisis regresi untuk memprediksi besaran variabel dependen yang dipengaruhi oleh variabel independen dengan persamaan sebagai berikut (Misbahuddin \& Hasan, 2014):

$$
Y=a+b_{1} X_{1}+b_{2} X_{2}
$$

Kemudian, dilakukan uji $\mathrm{F}$ untuk mengetahui kelayakan dari persamaan yang diperoleh dengan rumus sebagai berikut (Sugiyono, 2014):

$$
F_{\text {hitung }}=\frac{R^{2} / k}{1-R^{2} /(n-k-1)}
$$

Setelah dilakukan uji $\mathrm{F}$, selanjutnya dilakukan uji t untuk mengetahui apakah terdapat pengaruh yang signifikan variabel independen terhadap variabel dependen dengan rumus sebagai berikut (Sugiyono, 2019):

$$
t_{\text {hitung }}=\frac{r \sqrt{n-k-1}}{\sqrt{1-r^{2}}}
$$

\section{HASIL DAN PEMBAHASAN}

\subsection{Validitas Instrumen}

Berdasarkan hasil perhitungan dengan menggunakan rumus Aiken's V, diperoleh ratarata validitas isi instrumen tes kemampuan numerik dan instrumen tes kemampuan spasial pada Tabel 2 berikut.

Tabel 2. Rata-rata Validitas Isi Instrumen Tes Kemampuan Numerik dan Tes Kemampuan Spasial

\begin{tabular}{clcc}
\hline No & \multicolumn{1}{c}{ Validitas Isi } & Rata-rata & Kategori \\
\hline 1 & Tes Kemampuan Numerik & 0,96 & Sangat Valid \\
2 & Tes Kemampuan Spasial & 0,94 & Sangat Valid \\
\hline
\end{tabular}

Tabel 2 di atas menunjukkan bahwa rata-rata validitas isi instrumen tes kemampuan numerik sebesar 0,96 dan rata-rata validitas isi instrumen tes kemampuan spasial sebesar 0,94. Maka instrumen tes kemampuan numerik dan instrumen tes kemampuan 
spasial tergolong sangat valid dan telah memenuhi kriteria untuk dijadikan alat pengambilan data dalam penelitian.

\subsection{Analisis Statistik Deskriptif Data Hasil Penelitian}

Berdasarkan hasil analisis statistik deskriptif untuk kemampuan numerik siswa, diperoleh nilai maksimum 85, nilai minimum 25, rata-rata 56 dan standar deviasi 19,405. Dari rata-rata dan standar devisiasi tersebut, maka dapat dilakukan pengategorian hasil tes kemampuan numerik siswa pada Tabel 3 berikut.

Tabel 3. Pengategorian Kemampuan Numerik

\begin{tabular}{ccc}
\hline Interval Nilai & Banyak Siswa & Kategori \\
\hline $\boldsymbol{X}_{\mathbf{1}}>85,1075$ & 0 & Sangat Tinggi \\
$65,7025<\boldsymbol{X}_{\mathbf{1}} \leq 85,1075$ & 11 & Tinggi \\
$46,2975<\boldsymbol{X}_{\mathbf{1}} \leq 65,7025$ & 7 & Sedang \\
$26,8925<\boldsymbol{X}_{\mathbf{1}} \leq 46,2975$ & 10 & Rendah \\
$\boldsymbol{X}_{\mathbf{1}}<26,8925$ & 2 & Sangat Rendah \\
\hline Jumlah & 30 & \\
\hline
\end{tabular}

Untuk analisis statistik deskriptif kemampuan spasial siswa, diperoleh nilai maksimum 80, nilai minimum 30, rata-rata 56 dan standar deviasi 14,645. Dari rata-rata dan standar devisiasi tersebut, maka dapat dilakukan pengategorian hasil tes kemampuan spasial siswa pada Tabel 4 berikut.

Tabel 4. Pengategorian Kemampuan Spasial

\begin{tabular}{ccc}
\hline Interval Nilai & Banyak Siswa & Kategori \\
\hline $\boldsymbol{X}_{\mathbf{2}}>77,9675$ & 2 & Sangat Tinggi \\
$63,3225<\boldsymbol{X}_{\mathbf{2}} \leq \mathbf{7 7 , 9 6 7 5}$ & 11 & Tinggi \\
$48,6775<\boldsymbol{X}_{\mathbf{2}} \leq 63,3225$ & 9 & Sedang \\
$34,0325<\boldsymbol{X}_{\mathbf{2}} \leq 48,6775$ & 5 & Rendah \\
$\boldsymbol{X}_{\mathbf{2}}<34,0325$ & 3 & Sangat Rendah \\
\hline Jumlah & 30 & \\
\hline
\end{tabular}

Untuk analisis statistik deskriptif hasil belajar matematika siswa, diperoleh nilai maksimum 90, nilai minimum 40, rata-rata 68,33 dan standar deviasi 11,769. Dari ratarata dan standar devisiasi tersebut, maka dapat dilakukan pengategorian nilai hasil belajar matematika siswa pada Tabel 5 berikut.

Tabel 5. Pengategorian Hasil Belajar Matematika

\begin{tabular}{ccc}
\hline Interval Nilai & Banyak Siswa & Kategori \\
\hline $\boldsymbol{Y}>85,9835$ & 1 & Sangat Tinggi \\
$74,2145<\boldsymbol{Y} \leq 85,9835$ & 11 & Tinggi \\
$62,4455<\boldsymbol{Y} \leq 74,2145$ & 7 & Sedang \\
$50,6765<\boldsymbol{Y} \leq 62,4455$ & 10 & Rendah \\
$\boldsymbol{Y}<50,6765$ & 1 & Sangat Rendah \\
\hline Jumlah & 30 & \\
\hline
\end{tabular}




\subsection{Analisis Statistik Inferensial Data Hasil Penelitian}

Sebelum dilakukan uji hipotesis, terlebih dahulu dilakukan uji prasyarat. Adapun uji prasyarat yang harus dipenuhi adalah uji normalitas, uji linearitas, uji multikolinearitas, uji heteroskedasrisitas, dan uji autokorelasi. Uji normalitas dilakukan untuk mengetahui apakah sampel yang diteliti berasal dari populasi yang berdistribusi normal. Uji normalitas dilakukan terhadap data kemampuan numerik, kemampuan spasial, dan hasil belajar matematika siswa pada taraf signifikansi 0,05 dan hasilnya disajikan pada Tabel 6 berikut.

Tabel 6. Hasil Uji Normalitas

\begin{tabular}{llr}
\hline & & \multicolumn{2}{c}{$\begin{array}{c}\text { Unstandarddized } \\
\text { Residual }\end{array}$} \\
\hline $\mathrm{N}$ Normal Parameters ${ }^{\mathrm{a}, \mathrm{b}}$ & Mean & 30 \\
& Std. Deviation &, 0000000 \\
Most Extreme Differennces & Absolute & 5,69308823 \\
& Positive &, 113 \\
& Negative &, 077 \\
Test Statistic & &,- 113 \\
Asymp. Sig. (2-tailed) & &, 113 \\
\hline
\end{tabular}

Tabel 6 menunjukkan bahwa nilai signifikansi dari data kemampuan numerik, kemampuan spasial, dan hasil belajar matematika siswa adalah 0,200 > 0,05. Dengan demikian, dapat disimpulkan bahwa data dari hasil tes kemampuan numerik, kemampuan spasial, dan hasil belajar matematika siswa berasal dari populasi yang berdistribusi normal.

Selanjutnya dilakukan uji linearitas yang bertujuan untuk mengetahui apakah bentuk/model regresi X terhadap Y linear atau tidak. Uji linearitas dilakukan terhadap data kemampuan numerik dengan data hasil belajar matematika siswa dan juga terhadap data kemampuan spasial dengan data hasil belajar matematika siswa pada taraf signifikansi 0,05. Hasil uji linearitas disajikan pada Tabel 7 berikut.

Tabel 7. Hasil Uji Linearitas

\begin{tabular}{lcc}
\hline \multicolumn{1}{c}{ Variabel Independen } & F & Nilai Sig. \\
\hline $\begin{array}{l}\text { Kemampuan Numerik*Hasil } \\
\text { Belajar Matematika Siswa }\end{array}$ & 1,765 & 0,141 \\
$\begin{array}{l}\text { Kemampuan Spasial*Hasil } \\
\text { Belajar Matematika Siswa }\end{array}$ & 0,989 & 0,480 \\
\hline
\end{tabular}

Berdasarkan Tabel 7 diperoleh nilai Deviation from Linearity Sig. untuk kemampuan numerik terhadap hasil belajar matematika siswa adalah 0,141 >0.05. Maka dapat disimpulkan bahwa terdapat hubungan yang linear antara kemampuan numerik terhadap hasil belajar matematika siswa. Dan diperoleh nilai Deviation from Linearity Sig. untuk kemampuan spasial terhadap hasil belajar matematika siswa adalah 0,480 > 
0,05. Maka dapat disimpulkan bahwa terdapat hubungan yang linear antara kemampuan spasial terhadap hasil belajar matematika siswa.

Uji multikolinearitas digunakan untuk mengetahui apakah terdapat hubungan yang cukup kuat antar variabel bebas. Uji multikolinearitas dalam penelitian ini dilakukan terhadap data kemampuan numerik dan data kemampuan spasial menggunakan nilai Tolerance, dengan kriteria nilai Tolerance lebih besar dari 0,10. Hasil uji multikolinearitas disajikan pada Tabel 8 berikut.

Tabel 8. Hasil Uji Multikolinearitas

\begin{tabular}{lccc}
\hline \multirow{2}{*}{ Model } & \multirow{2}{*}{ Sig. } & \multicolumn{2}{c}{ Collinearity Statistics } \\
\cline { 3 - 4 } & 0,000 & Tolerance & VIF \\
\hline Kemampuan Numerik & 0,398 & 2,513 \\
Kemampuan Spasial & 0,045 & 0,398 & 2,513 \\
\hline
\end{tabular}

Tabel 8 menunjukkan bahwa nilai Tolerance untuk kedua variabel kemampuan numerik dan kemampuan spasial adalah 0,398 $>0,10$. Dengan demikian, dapat disimpulkan tidak terjadi multikolinearitas antara variabel kemampuan numerik dan variabel kemampuan spasial.

Selanjutya uji heteroskedastisitas digunakan untuk menguji terjadinya perbedaan variance dari nilai residual pada suatu periode pengamatan ke periode pengamatan yang lainnya. Uji heteroskedastisitas dalam penelitian ini dilakukan dengan mengamati grafik scatterplot. Pada grafik scatterplot dapat dilihat bahwa titik tersebar di sekitar nol pada sumbu vertikal dan tidak membentuk pola tertentu atau terlihat acak, maka dapat disimpulkan bahwa data tidak mengandung heteroskedastisitas.

Uji autokorelasi digunakan untuk mengetahui apakah dalam model regresi linear terdapat korelasi antara kesalahan pengganggu pada periode $\mathrm{t}$ dengan kesalahan pengganggu pada periode t-1 (sebelumnya). Uji autokorelasi dalam penelitian dilakukan terhadap data kemampuan numerik dan data kemampuan spasial menggunakan nilai Durbin-Watson (DW), dengan kriteria jika nilai DW berada di antara -2 dan +2 . Hasil uji autokorelasi disajikan pada Tabel 9 berikut.

Tabel 9. Hasil Uji Autokorelasi

\begin{tabular}{rlrrrr}
\hline Model & $\mathrm{R}$ & R Square & $\begin{array}{c}\text { Adjusted R } \\
\text { Square }\end{array}$ & $\begin{array}{c}\text { Std. Error of the } \\
\text { Estimate }\end{array}$ & $\begin{array}{c}\text { Durbin- } \\
\text { Watson }\end{array}$ \\
\hline 1 &, $875^{\mathrm{a}}$ &, 766 &, 749 & 5,900 & 1,639 \\
\hline
\end{tabular}

Tabel 9 menunjukkan bahwa nilai DW sebesar 1,639. Dengan melihat nilai tabel DW signifikansi $5 \%$ dengan $(2 ; 30)$ diperoleh dL sebesar 1,284 dan dU sebesar 1,567 . Jadi nilai DW 1,639 > 1,567 (dU) dan nilai DW sebesar 1,639<2,433 (4-dU). Sehingga nilai DW terletak antara dU dan $(4-d U)$. Maka dapat disimpulkan tidak terjadi autokorelasi di antara data pengamatan. Setelah data yang diperoleh berdistribusi 
normal, berpola linear, tidak terjadi masalah multikolinearitas, heteroskedastisitas, dan autokorelasi maka dilanjutkan dengan uji hipotesis.

Tabel 10. Hasil Analisis Regresi Sederhana Kemampuan Numerik Terhadap Hasil Belajar Matematika

\begin{tabular}{llrrrrr}
\hline & & \multicolumn{2}{c}{$\begin{array}{l}\text { Unstandardized } \\
\text { Model }\end{array}$} & \multicolumn{2}{c}{$\begin{array}{c}\text { Standardized } \\
\text { Coefficients }\end{array}$} & \multicolumn{2}{c}{ Coefficients } & & \multirow{2}{*}{ S } \\
\cline { 3 - 4 } & & \multicolumn{1}{c}{ B } & Std. Error & Beta & & \\
\hline \multirow{2}{*}{1} & (Constant) & 39,359 & 3,538 & & 11,125 &, 000 \\
& Numerik (X1) &, 517 &, 060 &, 853 & 8,652 &, 000 \\
\hline
\end{tabular}

Tabel 11. Hasil Koefisien Determinasi Variabel Kemampuan Numerik

\begin{tabular}{crrrr}
\hline Model & R & R Square & $\begin{array}{c}\text { Adjusted R } \\
\text { Square }\end{array}$ & $\begin{array}{c}\text { Std. Error of the } \\
\text { Estimate }\end{array}$ \\
\hline $\mathbf{1}$ &, $853^{\mathrm{a}}$ &, 728 & 718 & 6,249 \\
\hline
\end{tabular}

Berdasarkan Tabel 10 diperoleh nilai $a=39,359$ dan $b=0,517$ dengan persamaan regresi sederhana $Y=a+b X$, sehingga persamaan regresi kemampuan numerik terhadap hasil belajar yaitu $Y=39,359+0,517 X$.

Tabel 12. Hasil Analisis Regresi Sederhana Kemampuan Spasial Terhadap Hasil Belajar Matematika

\begin{tabular}{|c|c|c|c|c|c|c|}
\hline \multirow{2}{*}{\multicolumn{2}{|c|}{ Model }} & $\begin{array}{r}\text { Unstand } \\
\text { Coeffi }\end{array}$ & $\begin{array}{l}\text { ardized } \\
\text { ients }\end{array}$ & $\begin{array}{l}\text { Standardized } \\
\text { Coefficients }\end{array}$ & \multirow[t]{2}{*}{$\mathrm{T}$} & \multirow[t]{2}{*}{ Sig. } \\
\hline & & B & Std. Error & Beta & & \\
\hline 1 & $\begin{array}{c}\text { (Constant) } \\
\text { Numerik (X1) }\end{array}$ & $\begin{array}{r}32,996 \\
631\end{array}$ & $\begin{array}{r}5,437 \\
094\end{array}$ & 785 & $\begin{array}{l}6,069 \\
6711\end{array}$ & , 000 \\
\hline
\end{tabular}

Tabel 13. Hasil Koefisien Determinasi Variabel Kemampuan Spasial

\begin{tabular}{|c|c|c|c|c|}
\hline Model & $\mathrm{R}$ & R Square & $\begin{array}{c}\text { Adjusted R } \\
\text { Square }\end{array}$ & $\begin{array}{l}\text { Std. Error of the } \\
\text { Estimate }\end{array}$ \\
\hline 1 &, $785^{\mathrm{a}}$ & ,617 & 603, & 7,416 \\
\hline
\end{tabular}

Berdasarkan Tabel 12 diperoleh nilai $a=32,996$ dan $b=0,631$ dengan persamaan regresi sederhana $Y=a+b X$, sehingga persamaan regresi kemampuan spasial terhadap hasil belajar yaitu $Y=32,996+0,631 X$.

Tabel 14. Hasil Analisis Regresi Berganda Kemampuan Numerik dan Spasial Terhadap Hasil Belajar Matematika

\begin{tabular}{|c|c|c|c|c|c|c|}
\hline \multirow{2}{*}{\multicolumn{2}{|c|}{ Model }} & \multicolumn{2}{|c|}{$\begin{array}{l}\text { Unstandardized } \\
\text { Coefficients }\end{array}$} & \multirow{2}{*}{$\begin{array}{c}\begin{array}{c}\text { Standardized } \\
\text { Coefficients }\end{array} \\
\text { Beta }\end{array}$} & \multirow[t]{2}{*}{$\mathrm{T}$} & \multirow[t]{2}{*}{ Sig. } \\
\hline & & $\mathrm{B}$ & Std. Error & & & \\
\hline \multirow[t]{3}{*}{1} & (Constant) & 33,581 & 4,328 & & 7,759 &, 000 \\
\hline & Numerik (X1) & ,372 & 090 & ,613 & 4,151 &, 000 \\
\hline & Spasial (X2) & 249 & ,119 & ,310 & 2,099 & 045 \\
\hline
\end{tabular}


Tabel 15. Hasil Koefisien Determinasi Variabel Kemampuan Numerik dan Spasial

\begin{tabular}{lrrrr}
\hline Model & $\mathrm{R}$ & R Square & $\begin{array}{c}\text { Adjusted R } \\
\text { Square }\end{array}$ & $\begin{array}{c}\text { Std. Error of the } \\
\text { Estimate }\end{array}$ \\
\hline 1 &, $875^{\mathrm{a}}$ &, 766 &, 749 & 5,900 \\
\hline
\end{tabular}

Berdasarkan Tabel 14 diperoleh nilai $a=33,581, b_{1}=0,372$ dan $b_{2}=0,249$ dengan persamaan regresi sederhana $Y=a+b_{1} X_{1}+b_{2} X_{2}$, sehingga persamaan regresi kemampuan numerik dan spasial terhadap hasil belajar yaitu $Y=33,581+0,372 X_{1}+$ $0,249 X_{2}$.

Berdasarkan hasil analisis statistik inferensial yang telah dilakukan diketahui bahwa pengaruh kemampuan numerik terhadap hasil belajar matematika siswa adalah sebesar 72,8\% dan sisanya dipengaruhi oleh fakor lain. Besarnya pengaruh ini dituliskan dalam bentuk persamaan regresi, yaitu $\hat{Y}=39,359+0,517 X$. Persamaan regresi ini menunjukkan apabila nilai kemampuan numerik bertambah 1 satuan, maka nilai hasil belajar akan bertambah 0,517 dan ditambah dengan 39,359. Hasil penelitian ini sejalan dengan hasil penelitian yang dilakukan oleh Setyawan dan Amir (2020) yang menyatakan bahwa terdapat pengaruh kemampuan numerik terhadap hasil belajar matematika peserta didik. Adanya pengaruh dan kontribusi kemampuan numerik terhadap hasil belajar matematika siswa menunjukkan bahwa kemampuan numerik penting untuk dimiliki dan dikembangkan pada diri setiap siswa. Kemampuan numerik yang baik memudahkan seseorang dalam mengelola angka dan logika dengan aktivitas utama berpikir logis, melakukan perhitungan matematis, memecahkan masalah, dan menyusun pola-pola hubungan. Dengan kemampuan tersebut akan memudahkan seseorang untuk melakukan interpretasi berbagai ide matematis dalam bentuk simbolsimbol. Seseorang dengan kemampuan numerik tinggi memperlihatkan kecenderungan suka melakukan aktivitas berhitung dan memiliki kecepatan tinggi dalam menyelesaikan soal-soal atau masalah matematika (Irawan, 2016). Menurut Gunur, Makur, dan Ramda (2018) sebagian besar materi yang ada dalam mata pelajaran matematika membutuhkan banyak sekali perhitungan dan membutuhkan kemampuan khusus yang dapat menunjang proses penyelesaiannya. Oleh karena itu, dalam mempelajari matematika siswa dituntut untuk mempunyai kemampuan mengelola angka, berpikir logis, melakukan perhitungan matematis, dan memecahkan masalah. Dengan demikian, kemampuan numerik yang berkembang dengan baik dalam diri siswa mampu membantunya dalam memperoleh hasil belajar matematika yang baik pula.

Hasil penelitian ini juga menunjukkan bahwa terdapat pengaruh kemampuan spasial terhadap hasil belajar matematika siswa, dengan pengaruh sebesar $61,7 \%$. Besarnya pengaruh tersebut dapat dituliskan dalam bentuk persamaan regresi, yaitu $\mathrm{Y} \stackrel{\wedge}{=} 32,996$ $+0,631 X$. Persamaan regresi ini menunjukkan apabila nilai kemampuan spasial bertambah 1 satuan, maka nilai hasil belajar akan bertambah 0,631 dan ditambah dengan 32,996. Hasil penelitian ini sejalan dengan hasil penelitian yang dilakukan oleh 
Inayah dan Sugiarni (2019) yang menyatakan bahwa terdapat pengaruh kemampuan spasial terhadap hasil belajar matematika siswa. Hasil penelitian ini juga sejalan dengan pendapat Tambunan (2006) yang menyatakan kemampuan spasial ini menunjukkan kemampuan siswa dalam memahami perspektif ruang dan dimensi, memahami abstrak meliputi persepsi spasial yang melibatkan hubungan spasial termasuk orientasi sampai pada kemampuan yang rumit yang melibatkan manipulasi serta rotasi mental. Dalam kemampuan ini diperlukan adanya pemahaman kiri kanan, pemahaman perspektif, bentuk-bentuk geometris, menghubungkan konsep spasial dengan angka dan kemampuan dalam transformasi mental dari bayangan visual. Pemahaman tersebut sangat diperlukan ketika belajar matematika. Oleh karena itu, penelitian ini menunjukkan bahwa semakin tinggi tingkat kemampuan spasial yang dimiliki oleh siswa maka akan dapat meningkatkan hasil belajar matematika yang optimal.

Selanjutnya hasil penelitian ini juga menunjukkan terdapat pengaruh kemampuan numerik dan spasial terhadap hasil belajar matematika siswa, dengan pengaruh sebesar 76,6\%. Besarnya pengaruh ini dituliskan dalam bentuk persamaan regresi, yaitu $\hat{Y}=32,996+0,631 X$. Persamaan regresi ini menunjukkan apabila kemampuan numerik dan spasial bertambah 1 satuan, maka nilai hasil belajar akan bertambah 0,372 dari kemampuan numerik, ditambah dengan 0,249 dari kemampuan spasial, dan ditambah dengan 33,581 dari faktor lain yang mempengaruhi. Hasil penelitian ini sejalan dengan hasil penelitian yang dilakukan oleh Acdiyat dan Utomo (2017) yang menyatakan bahwa terdapat pengaruh yang signifikan antara kecerdasan visualspasial dan kecerdasan numerik secara bersama-sama terhadap prestasi belajar matematika siswa. Hasil penelitian ini juga diperkuat dengan pendapat sebelumnya yang menyatakan bahwa kemampuan numerik dalam pelajaran matematika sangat membantu dalam berhitung, mengukur dengan menggunakan angka-angka, memecahkan soal-soal matematika, membuat pola-pola serta mampu berpikir dengan logis. Dengan kemampuan numerik yang baik akan sangat membantu dalam memperoleh hasil belajar yang maksimal. Sedangkan kemampuan spasial merupakan kemampuan yang meliputi kepekaan pada warna, garis, bentuk, ruang, dan hubungan antar unsur tersebut. Kemampuan spasial sangat erat kaitannya dengan pelajaran matematika, karena sangat banyak materi yang ada dalam mata pelajaran matematika yang membutuhkan kemampuan spasial ini, sehingga siswa yang memiliki kemampuan spasial yang tinggi dapat menghasilkan hasil belajar matematika yang tinggi pula. Dengan demikian, siswa yang memiliki kemampuan mengelola angka dan logika dengan baik serta didukung dengan kemampuan imajinasi atau membaca gambar dengan baik, maka akan memudahkan siswa dalam mengekspresikan ide-ide matematika secara tertulis dengan menggunakan simbol matematika dalam menyelesaikan masalah. Dengan kata lain, semakin tinggi kemampuan seseorang dalam melakukan perhitungan matematis, memecahkan masalah, berpikir logis, dan mampu menyusun pola-pola hubungan dan didukung oleh kemampuan yang tinggi dalam mengimajinasikan atau membayangkan perubahan-perubahan yang terjadi pada 
gambar setelah mengalami rotasi serta menentukan persamaan dan perbedaan gambar, maka semakin tinggi pula hasil belajar matematikanya.

\section{SIMPULAN}

Bagian ini memaparkan simpulan penelitian sesuai dengan hasil dan temuan penelitian. Bagian ini tidak perlu ada kutipan atas simpulan. Kesimpulan menggambarkan jawaban atas hipotesis dan / atau tujuan penelitian atau temuan ilmiah yang diperoleh. Kesimpulan tidak mengandung pengulangan hasil dan diskusi, melainkan merangkum temuan seperti yang diharapkan dalam tujuan atau hipotesis.

Berdasarkan hasil penelitian ini, diperoleh bahwa hasil belajar matematika siswa dipengaruhi oleh kemampuan numerik dan kemampuan spasial.

1. Terdapat pengaruh kemampuan numerik terhadap hasil belajar matematika siswa kelas VIII SMPN 2 Labuapi. Besarnya pengaruh kemampuan numerik terhadap hasil belajar matematika siswa adalah $72,8 \%$.

2. Terdapat pengaruh kemampuan spasial terhadap hasil belajar matematika siswa kelas VIII SMPN 2 Labuapi. Besarnya pengaruh kemampuan numerik terhadap hasil belajar matematika siswa adalah $61,7 \%$.

3. Terdapat pengaruh kemampuan numerik dan spasial terhadap hasil belajar matematika siswa kelas VIII SMPN 2 Labuapi. Besarnya pengaruh kemampuan numerik dan kemampuan spasial terhadap hasil belajar matematika siswa adalah $76,6 \%$. Dengan demikian, semakin baik kemampuan numerik seseorang yang didukung dengan kemampuan spasial yang baik, maka akan berdampak pada hasil belajar matematika yang baik pula.

\section{REFERENSI}

Achdiyat, M \& Utomo, R. (2017). Kecerdasan visual-spasial, kemampuan numerik, dan prestasi belajar matematika. Jurnal Formatif, (Vol. 7(3), pp. 234- 245).

Gunur, B., Makur, A. P., \& Ramda, A. H. (2018). Hubungan antara kemampuan numerik dengan kemampuan pemecahan masalah matematis siswa di pedesaan. MaPan: Jurnal Matematika dan Pembelajaran, (Vol. 16(2), pp. 148-160).

Indrawati, F. (2013). Pengaruh kemampuan numerik dan cara belajar terhadap hasil belajar matematika siswa. Jurnal Formatif, (Vol. 3(3), pp. 215-223).

Harmony, J \& Theis, R. (2012). Pengaruh kemampuan spasial terhadap hasil belajar matematika siswa kelas VIII SMP negeri 9 kota jambi. Jurnal Edumatica, (Vol. 2(1), pp. 11-19).

Inayah, S \& Sugiarni, R. (2019). Pengaruh kemampuan spasial terhadap hasil belajar matematika siswa. Jurnal Matematika Ilmiah STKIP Muhammadiyah Kuningan, (Vol. 5(2), pp. 130-142).

Irawan, A. (2014). Pengaruh kecerdasan numerik dan penguasaan konsep matematika terhadap kemampuan berpikir kritik matematika. Jurnal Formatif, (Vol. 4(1), pp. 46-55).

Irawan, A. (2016). Peranan kemampuan numerik dan verbal dalam berpikir kritis matematika pada tingkat sekolah menengah atas. AdMathEdu: Jurnal Ilmiah Pendidikan Matematika, Ilmu Matematika dan Matematika Terapan, (Vol. 6(2), pp. 121-130). 
Jayantika, N. T., Ardana, I. M., \& Sudiarta, P. (2013). Kontribusi bakat numerik, kecerdasan spasial, dan kecerdasan logis matematis terhadap perstasi belajar matematika siswa SD negeri di kabupaten buleleng. Jurnal Jurusan Pendidikan Matematika Ganesha, (Vol. 2(1), pp. 1-12).

Misbahuddin \& Hasan, I. (2014). Analisis data penelitian dengan statistik. Jakarta: Bumi Aksara.

Novitasari, D., Rahman, A., \& Alimuddin. (2015). Profil kreativitas siswa dalam pemecahan masalah ditinjau dari kecerdasan visual spasial dan logis matematika pada siswa SMAN 3 makassar. Jurnal Daya Matematis, (Vol. 3(1), pp. 41-50).

Riwidikdo, H. (2010). Statistik untuk penelitian kesehatan dengan aplikasi program $r$ dan spss. Yogyakarta: Pustaka Rihama.

Slameto. (2013). Belajar dan faktor-faktor yang mempengaruhinya. Jakarta: Rineka Cipta.

Setyawan, D \& Amir, A. (2020). Pengaruh kemampuan numerik terhadap hasil belajar matematika pada peserta didik kelas VIII SMP negeri 11 maros baru. Equals, (Vol. 3(2), pp. 85-94).

Sugiyono. (2014). Metode penelitian kombinasi (mixed methods). Bandung: Alfabeta.

Sugiyono. (2019). Statistika untuk penelitian. Bandung: Alfabeta.

Tambunan, S. M. (2006). Hubungan antara kemampuan spasial dengan prestasi belajar matematika. Jurnal Makara Sosial Humaniora, (Vol. 10(1), pp. 27-32). 